\title{
The Highs and Lows of the Reception to the Works of Lu Xun in Middle School Chinese Textbooks from the 1920s to 2017
}

\section{Yang $\mathrm{Ke}$}

\author{
Central China Normal University, Wuhan, China
}

\section{Abstract}

Lu Xun (1881-1936) is one of the most important Chinese twentieth century cultural figures who had addressed a number of social concerns in his works and attracted numerous readers both in China and abroad. He is such an iconic figure in China that he is easily identifiable by the following description of this Chinese saying: "His short hairs stood up like brushes. His thick moustache looked like a character "-” of the calligraphical style used in Han Dynasty..."

The paper discusses how Lu Xun was so highly regarded in China in the context of the roles and functions of intellectuals in the country. But while outside China literature scholars and students generally see Lu Xun's reputation in the Chinese literary canon as solidly established, in China, that did not seem to not have been the case historically. This apparent instability in his status in the Chinese canon is what this paper tries to investigate as may be gleaned from the controversies surrounding the alleged "retreat of Lu Xun in China." In particular, this paper focuses on the changes in the representation of Lu Xun's works in the Middle School and High School Chinese textbooks from the 1920s to 2017 owing to conflicting attitudes and ideas in Chinese history, society, and politics. Finally, it analyses the competing positions over the 
"reshuffling of textbooks" in China involving the alleged exclusion of works by $\mathrm{Lu}$ Xun resulting from his increasingly unstable status in the Chinese literary canon, and the further reduction in the number of his works left represented in Chinese textbooks.

\section{Keywords}

$\mathrm{Lu}$ Xun, literary canon, Mao Zedong, literature textbooks, modern Chinese fiction 


\section{Lu Xun and his time}

$\mathrm{Lu}$ Xun, the pen name of Zhou Shuren, was born to a scholar-official family in Shaoxing, southeastern China, in 1881. His childhood education made him well-versed in the Chinese classical tradition. When he grew older, the family's financial crisis and the abolition of the Chinese Imperial Examination in 1905 prevented him from becoming a scholar-bureaucrat, usually the path taken professionally by the literati since ancient times in China. Thus, he studied first at the newly organized schools in China which exposed him to ideas antithetical to those he had received previously from his traditional education. It was not easy for him because at that time, "anyone who studied 'foreign subjects"” was regarded as a social outcast, "someone who could find no way out and was forced to sell his soul to foreign devils" ("Call to Arms" $5)$.

The reason is that the traditional Chinese educational system mainly focused on memorization and mastery of the Confucian classics, as well as training on the prescribed protocols for writing in order to pass the Chinese Imperial Examination. Students' performance was evaluated according to their exact imitation of the Confucian classics rather than on their analytical merits or critical way of thinking. But by the late 19th century, with the failure of the Opium Wars, modern or Western methods of education were introduced by westerners in China. New subjects that emphasized scientific training began to be taught in some newly organized schools. Although the Emperor (GuangXu) and the officials in the Qing Dynasty had foreseen the benefits to be derived from this scientific and practical education for the Chinese public, the perception was that it was "foreign" because it was brought in by the foreign invaders. As such, negative responses were generated that looked down upon the foreign subjects and those who had been required to study them were regarded with disdain and rejection. Lu Xun himself confessed that he had hesitated to attend the new school but because it offered financial support which could reduce the burden on his family, he decided to receive foreign education eventually.

After four years of this Western-type of education learning about mining, chemistry, English, and evolution, Lu Xun won a scholarship to 
study Western medicine in Japan in 1902. The sad memories of his father's illness made him imagine that someday, there would be "a glorious future... in which I would return to my homeland after graduation and set about medicating its suffering sick . . . all the while converting my fellow countrymen to the religion of political reform" (Lovell, "China's conscience”). In 1906, due to what he felt was the great indifference of his countrymen to the nation's tragedy, he decided to abandon his medical studies and began literary study in order to forge "new paths, opening himself to novel places, while searching for a new breed of people with different characteristics-a new personality" (Lu Xun 1981, 415).

His lifetime was a tumultuous time for China. He saw the fall of the Qing dynasty (1642-1911), the rise of the Republic of China (1912-1949), and the founding of the Chinese Communist Party in 1921. With important political and cultural reforms taking place in the wake of the mid-19th century Opium Wars, the Chinese literary scene became closely linked with major historical developments and political movements. The failure in the war with England in 1840 brought China a series of misfortunes that the country had never experienced in the past. Finally, "the Chinese began to doubt anything of their traditional culture." This doubt began to help shape the May Fourth Movement in 1919 that would seek to "overthrow all traditional Chinese cultures and rebuild their culture by learning everything from the West civilizations..." (Dawson 80-81). The changes that resulted from these developments would be woven tightly into Lu Xun's works.

After having studied in Japan from February 1902 to June 1909, Lu Xun returned to China in the midst of great upheavals. However, although he experienced one difficulty after another upon his return, he chose to face the country's tragedy with the spirit of self-critique and confront reality in the face through his writings. He established himself as one of the most important writers in the Chinese new vernacular literature movement with his first short story, "Diary of a Madman," published in the revolutionary periodical New Youth in 1918 and now considered to be one of the first and more influential modern works written in vernacular Chinese. Indeed, Lu Xun's works validate the claim that the new vernacular literature singularly 
raised the critical awareness of the Chinese masses about the link between traditional Confucianism and cannibalism at that time as may be gleaned from his works. It is from this perspective that Lu Xun may be said to have laid a solid foundation for the development of modern Chinese literature.

Meanwhile, the Beijing warlord government's surrender to Japan at the Versailles peace conference after World War I occasioned the students' protest march in 1919. This is the famous May Fourth Movement in China's history. It can be traced back to the "Literary Revolution" that had originated as early as 1917 by Hu Shi (1891-1962) and Chen Duxiu (1879-1942). Hu Shi published "Initial Discussion on the Reform of Literature" in the January 1917 issue of New Youth and claimed that the classical style of writing had lost its vitality, unable to adapt to the modern trend; hence, he believed that people should advocate the use of the vernacular and discard classical Chinese. ${ }^{1}$ Chen Duxiu echoed his call and appealed for a revolution in literature as well, calling for reforms in traditional Chinese culture and demanding the overthrow of Confucian moral principles which marked the beginning of the May Fourth Movement. The new way of regarding literature as the tool of modernization and enlightenment began.

Due to China's repeated failures and humiliations in the face of foreign invasions, the Chinese intellectuals became strongly critical of the study of Chinese tradition and classical language. Upon the urging of such intellectuals, Lu Xun decided to contribute to New Youth in 1918. But before doing so, Lu Xun recalled in his Preface for Call to Arms his initial concerns and subsequent decision to publish in New Youth. After his early attempts to awaken the Chinese people in his works believing that he had failed in his efforts, Lu Xun felt discouraged and decided to stay in Beijing doing nothing more than writing calligraphy and copying ancient inscriptions everyday to kill time. But one day in 1918, Lu Xun was asked by Qian Xuantong about the meaninglessness of copying inscriptions and urged him to write articles for New Youth. Lu Xun replied:

Suppose there was an iron house, sealed tight without a single window and virtually indestructible. Inside there are a large number of people fast asleep who within a short period of time will all die for lack of oxygen. Yet if they 
pass from the stupor of sleep into the extinction of death, they will be spared the agony of knowing they are about to meet with their own demise. Now if someone starts shouting and awakens a few of the lighter of these sleepers, but in so doing subjects them to the pain and suffering of inevitable death, would you, in fact, consider this to be doing them a favor?" (qtd. in Kowallis 28).

After hesitating for a while, Qian Xuantong replied, "since a few are aroused...you cannot insist that there remains absolutely no hope of breaking down the iron house" (qtd. in Kowallis 28). After this exchange, Lu Xun made up his mind to write articles for New Youth for the sake of awakening the "sound sleepers" from "the iron house," no matter how slight the chances were.

The term "intellectual" needs a closer examination because, literally, this word can be understood to mean officials (the learned ones who passed the Imperial Examination from ancient China until 1911, the fall of the Qing Dynasty), professionals, or anyone who had received a certain level of education. While it is understandable, therefore, that only those who had a certain educational background could be called intellectuals, in the historical context of China, other factors might be said to have been at play as well in such a consideration including how much freedom they had in order to publish their ideas and opinions or whether they were involved in government service or not.

There are many studies about the meaning of "intellectual" in the western academic world. Edward Shils, on the one hand, defines it as one among "a minority of persons who, more than the ordinary run of their fellow-men, are enquiring, and desirous of being in frequent communication with symbols which are more general than the immediate concrete situations of every life, and remote in their reference in both time and space" (3). On the other hand, Said has said that intellectuals are the "disturber of the status quo" (x). Thus, it may be said that intellectuals are associated with questions of power relations in society and are linked with matters of "symbolic capital and power" ("The Field" 166). This "symbolic power" ("In 
Other Words" 138) enables the intellectuals to make authoritative claims because they possess knowledge in the symbolic realm, which are associative of public recognition and influence in the sense that what they do and what they say can be easily paid attention to by the common public. From this perspective, it is not surprising why the New Youth eagerly wanted Lu Xun to write articles for them.

Traditionally, officialdom was the natural position for good scholars in the long imperial history of China. This is why the Chinese intellectuals historically have an ambivalent relationship with the dominant class within the field of power. In fact, Bourdieu emphasizes that intellectuals are "a dominated fraction of the dominant class" ("The Field" 145).

Since the Qing Dynasty was overthrown by the revolutionaries in 1911, the Chinese intellectuals enjoyed freedom for at least two decades until the Kuomintang took control of some parts of China in the 1930s. Without the Emperor, the ruling elite, and the traditional restraints of the past, the Chinese intellectuals became tremendously productive. One of the greatest intellectuals of the period was Lu Xun whose contributions to China deserve more than a passing glance.

After the founding of the People's Republic of China and several political movements during Mao Zedong's leadership in the 1950s and 1960s, the status of the intellectuals began to change. The intellectuals were no longer in their esteemed position as they were denigrated as the "stinking old ninth" (the Chinese saying to describe the most humble class in society) among "class enemies" (Thurston 21). Thus, most of the Chinese intellectuals were deprived of their rights to write and were forced to be silent until the end of the Cultural Revolution (1976). After the open-door policy and economic reform in 1978, China began to regard the intellectuals as an integrated part of the working class. Little by little, some of them resumed what their older generations had done and participated in the party leadership of modern China. The crucial difference at this juncture was that there no longer existed the traditional close relationship of the scholar-official class and the ruling class as had been the case in Chinese history and the intellectuals were 
no longer part of the dominant class but were now under the influence of the Communist Party, the Party-state, the new dominant class, so to speak.

On the one hand, the Party-state China needed the knowledge possessed by the intellectuals; on the other hand, the government was wary about the political threat (actual or potential) which the intellectuals might pose upon the country, specifically due to their possible influence on the masses. After China's serial policies to emphasize China's economic development in order to compete with other countries at the end of the 20th century and move towards a technocracy, some conflicts emerged between the government and the intellectuals. The intellectuals worried about the sustainability of China's economic growth as social and environmental problems gradually became serious and alerted the nation about the possible harm from utilitarianism. In the midst of this development, the intellectuals advocated for people to learn from the great Chinese figures and form the habit of critical thinking in order to understand the social reality. In this regard, a case in point is the status of $\mathrm{Lu}$ Xun in relation to the controversies about his changing representation in the Middle and High School Chinese textbooks in 2010. In his case, one sees a diverse range of positions defining the relationship between the intellectuals and the state that bears upon the changing reception to $\mathrm{Lu}$ Xun's works.

The following section discusses the so-called "retreat of Lu Xun" in China in relation to the formation of intellectuals and the reception to his works by Chinese critics in so far as the representation of his works in the textbooks is concerned.

\section{The "Retreat of Lu Xun in China"}

The discussion began on September 6, 2010, when Liu Yi, a Chinese intellectual, stated in his Twitter blog that there were over twenty Chinese classic literary works-such as "Thunderstorm" (by Cao Yu 1910-1996), "The Peacock Flies to the Southeast" (written in the Han Dynasty [202 B.C-220], author unknown), "Medicine" (Lu Xun [1881-1936]), "The True Story of Ah Q” (Lu Xun [1881-1936]), and “Miss Liu Hezhen” (Lu Xun [1881-1936]) which had been taken out of the High School Chinese textbooks and warned 
the Chinese public to be alert. His statement aroused heated discussions among the Chinese public especially among netizens. Liu described the "renewal of textbooks" in Chinese lessons for High Schools as the "exchange transfusion," alluding to the process of blood transfusion, which led to a kind of renewal or rejuvenation. Since several of Lu Xun's representative works which had been previously included were now excluded from High School Chinese textbooks, the whole case was dubbed by some commentators as the "Great Retreat of Lu Xun" (Lu Xun da chetui). ${ }^{2}$

From then on, Lu Xun's name understandably kept appearing in the media. It was nothing about his works or his ideas in general. What was being discussed heatedly was the alleged “expulsion” of Lu Xun's selected works from the Middle School and High School Chinese textbooks where he had been placed in a comfortable position since the mid-1920s. The discussion soon started getting out of control because the Internet allowed broad access to numerous readers. Netizens and online communities with opposite opinions quarreled with and criticized each other furiously and asked the government and authorities to give an explanation about the issue. In the discussions, various interpretations of Lu Xun's works appeared. Some of them obviously did not have an understanding of the case of Lu Xun nor did they seem to have first-hand knowledge of Lu Xun's works, yet, their participation in the discussions was also welcome. As a result, the literary community began to appeal for a critical reading of Lu Xun and classical Chinese literature.

However, judging from the Ministry of Education's subsequent clarification, People's Education Publisher's reports, newspaper accounts, discussions, and commentaries on the Internet and Chinese blogosphere, the "Great Retreat of Lu Xun" might have been, in a sense, a misperception or an exaggeration.

Firstly, Liu Yi's assertion that Lu Xun had been removed from the High School Chinese textbooks was due to his misunderstanding of the Chinese textbook reform under the state's new curriculum standard. The whole curriculum and textbook reform had been a long-standing process, happening not overnight, and beginning not recently, but at the beginning 
of the 21st century and extended to different provinces gradually. Provinces such as Guangdong and Hainan were the first participants at the start of the textbook reform. China consists of 23 provinces: 4 municipalities ${ }^{3}$ are directly under the central government, five autonomous regions ${ }^{4}$, and two special administrative regions. The changes that transpired had accumulated into a big snowball over the years of the reform process which led to the debate on the Internet in 2010.

Secondly, apart from the leading textbook publisher-People's Education Press (PEP)-there are now several publishers qualified to be textbook providers for the textbook reform. This means different regions can use different versions of the textbooks according to their different demands. Since different versions of the textbooks offered different selections of $\mathrm{Lu}$ Xun's works by the different publishers, the changes might have made the readers and the public feel that there had been really huge changes about Lu Xun's works in the Middle School and High School Chinese textbooks. For example, some netizens mentioned that "Miss Liu Hezhen" was axed from the new textbook in 2010; actually, this article had never appeared in the Guangdong province's textbook in the first place. But it was still kept in the version of PEP, the leading textbook publisher in China even today. Moreover, some provinces divided the teaching sections into compulsory and optional parts; because of this, Lu Xun's works appeared in different parts of the Middle School and High School Chinese textbooks, making the public feel that some of the works had been altogether removed from the textbook.

Still, some of the articles were transferred from the compulsory parts into optional ones, which, in itself, is arguably an important enough change. Worse, it is also true that "Medicine" and "The True Story of Ah Q" are two of Lu Xun's most famous short stories worldwide have been completely withdrawn from all six versions of the Chinese textbooks. But worst of all, the total number of Lu Xun's works in the Middle School and High School Chinese textbooks had been gradually reduced.

Apart from the discussions on the diminishing number of Lu Xun's works in the Middle School and High School Chinese textbook reform, there 
were a lot of disagreements on the underlying implications of the removal of Lu Xun's works. The spokeswoman of the Ministry of Education, Xu Mei, answered the questions about the "retreat of Lu Xun" on May 12, 2011, stating that "it is very tiny, fine-tuning; actually there was no such big adjustment at all" (Guo). According to her, there are six versions of the High School Chinese textbooks in China; they are published by Beijing Normal University Publishing House, Shandong People's Publishing House, Guangdong Education Press, Language Publishing House, and PEP. Among them, only the Guangdong Education Press version changed Lu Xun's "Medicine” to “The New-Year Sacrifice." Thus, what Liu Yi says is not entirely correct.

Although "the official line claimed that different generations require different textbooks to reflect different demands" (Sascha), the chief editor of Jiangsu Education Publishing Company stated that the removal of some of Lu Xun's works was due to their length and complexity which teenagers have difficulty in understanding and appreciating. Nevertheless, some Chinese commentators in the blogosphere held totally contradictory positions. They pointed to the political factors related to the government's ideology and appealed for Lu Xun's re-inclusion into the Chinese textbooks for the continuing relevance of the spirit of his works in today's materialistic world. Some western scholars such as Julia Lovell connected this issue with the Chinese government's alleged intention and said that "the beginnings of a Lu Xun's withdrawal from Chinese school textbooks began, partly to make way for escapist kung fu texts. Perhaps the intention was to vary the literary diet of the young. ... Perhaps also it was an attempt to discourage the youth of today from Lu Xun's hanging inconveniently faultfinding habits" (Lovell).

\section{The Changes of Lu Xun's Works in Middle and High School Chinese Textbooks from the 1920s to 2017}

In the midst of all these current debates and discussions, one wonders what standard might have been used that allowed so many of Lu Xun's works to be included in the Middle School and High School Chinese textbooks since the 1920s. In relation to the matter of inclusion, questions deserve an explanation: whether or not those selected works can be considered representa- 
tive of Lu Xun, and whether or not they play a positive role in promoting Chinese students' language performance, thought development, and reading comprehension ability. By tracing the historical changes of Lu Xun's works in the Middle School and High School Chinese textbooks from the 1920s to 2017, the above-mentioned observations might be validated. To be discovered as well are the factors that might have contributed to the selection of his works for Chinese textbooks and the relationships between them. However, due to the constraints of the availability of data before the founding of the People's Republic of China, only the general distribution of Lu Xun's works in the Middle School and High School Chinese textbooks was listed, although the total number of Lu Xun's works in certain periods were collected and presented. After the founding of the People's Republic of China, the data are mainly from the leading textbook publisher's version-PEP.

Since the life cycle of each version of the Chinese textbooks can last around 5 to 10 years, comparing the lists of Lu Xun's works in the Middle School and High School Chinese textbooks in different periods may help. This study classifies them in accordance with significant historical movements in China on the basis of the standard periodization of important episodes in modern Chinese history. They are from the 1920s (the period shortly after Lu Xun published his first vernacular story in 1918 and his works were included in the Middle School and High School Chinese textbooks) to 1949 (the founding of the People's Republic of China); from 1949 to 1966 (the steady development period to the start of the Cultural Revolution); from 1966 to 1976 (the Cultural Revolution); from 1977 (the period when China started to follow the Open Door policy and focused on the country's economic development) to 1999 (China's rapid development period after the Open Door policy); and from 2000 (the period of rapid economic growth) to 2017 (the period when China was moving toward globalization).

The reason for choosing these events as the basis of categorization is due to their serving as landmarks, after having had a strong influence on society, in many ways shaping the compilation of the Middle School and High School Chinese textbooks. 
Compared with the works of other contemporary writers, Lu Xun's works were included in the Chinese textbooks of Middle Schools and High Schools the most, with consistency and continuity during the past century. This fact has enabled the successful build-up of Lu Xun's canonical status and, ironically, has also attracted a great deal of perhaps overstated comments and criticism. As Chen Duxiu notes:

Before getting close to the political party, about 16 or 17 years after the establishment of the Republic of China, he was cursed worthless by the members of this party; as he got close to it, he continued to be highly regarded by them. It seems that Lu Xun used to be a dog that transformed into a god. Although Lu Xun is neither a dog nor a god. He is actually a man who has talents in literature. (24)

Generally speaking, "Textbooks best embody the political cultures of an era especially the content about the humanities. They serve as windows through which we can view how the political cultures change public's behaviors and customs" (Xie 365). Thus, to a certain extent, textbooks generally reflect the political cultures of a country and are important embodiments of the literary creations of a period. When the political, economic, and cultural systems are relatively stable, the adjustments are minor; in contrast, changes, even marked deletions and revisions, will be apparent when there are great social or economic transformations. Therefore, Lu Xun's works in the Middle School and High School Chinese textbooks became a barometer of the times. In this sense, the canon and the value assigned to the canon in association with the privilege accorded the author as author-function combine render it "useful" as cultural capital.

\section{The 1920s-1949}

In the early 1920s, Lu Xun's works already appeared in Chinese textbooks which were compiled by various domestic publishing companies and some famous universities, in spite of the fact that Lu Xun had just started writing his new-vernacular literature two or three years earlier. Based on the classification of Lu Xun's works for the Middle School and High School 
Chinese textbooks in the Republic of China (1922-1949), most compilations of Lu Xun's works for Middle School and High School concentrated on his stories and prose. The chosen principles upon which the selections were made were "either subjective prejudice or preference" (R. Wen et al 40). It may be said, therefore, that the construction of the canon in this period owed to preferences of compilers and the growing popularity of Lu Xun.

The earliest known Middle School Chinese textbook which contained the works of Lu Xun appeared in the early 1920s in Beijing KongDe school's Junior Middle School Chinese Selected Readings (《初中国文选读》) which included "Storm in a Teacup," "Hometown," "The Comedy of the Ducks," "Village Opera," "The Rabbits and the Cat," and "On the Fall of the Leifeng Pagoda” (Chen 123). Afterwards, readers began to frequently see Lu Xun's works in all kinds of textbooks such as in August 1923, Shanghai Commercial Press published New Education System Chinese Textbook (Xinxuezhi yuwen jiaokeshu), compiled by Fan Xiangsan, edited by $\mathrm{Hu}$ Shi et al., which contained "Hometown" and "The Comedy of the Ducks" (Wang and Deng 54). Also, the Curriculum Standards for New School System: Middle School Chinese Course Outline (《新学制课程标准:初级中学国语课程纲要》) by Ye Shaojun and Hu Shi in May 1923 stated clearly that Lu Xun's Story Collection (not yet published at that time) had been included in the minimum reading requirements for graduates (Curriculum Research Institute 276). Moreover, the following books contained Lu Xun's works: Mandarin ( 《国 语》) which was edited by Ye Shaojun for the new educational system in 1924; Revival Junior Middle School Chinese Textbook（《复兴初级中学国文 教科书》) edited by Fu Donghua in 1934; and Intensive Reading Guidance and Brief Reading Guidance (《精读指导举隅》和《略读指导举隅》) co-edited by Ye Shaojun and Zhu Ziqing in the 1940s (Wang and Deng 55). Apparently, Lu Xun's works initially did not appear in the official Middle School Chinese textbook but in some famous private schools' Chinese textbooks indicating clearly the historical origin of Lu Xun's important role in the Middle School Chinese textbooks and popularity among the public. 
In consideration of the numerous Chinese textbooks during the period of the Republic of China (1912-1949), this study has focused on three major publishers- Shanghai Commercial Press, Zhonghua Book Company, and Shanghai World Publishing House-covering the period from the 1920s to 1949 to analyze the changes in the representation of Lu Xun's works in Chinese Textbooks (Zhou Haiying).

Based on Lu Xun's works which were included in the textbooks by the three major publishers during the time of the Republic of China, the main works, classified into genres, including the translation by Lu Xun, are as follows:

Prose:

“Autumn Night”《秋夜》

"Snow" 《雪》

“The Kite”《风笔》

“The Good Story” 《好的故事》

“The Wise, the Fool and the Flunkey”《聪明人和俊子和奴才》

“Mr. Fujino" 《藤野先生》

“Father's Illness”《父亲的病》

“From Baicao Garden to Three Flavor Study”《从百草园到三味书屋》

“Winter Leaves” 《腊叶》

Story: “Kong Yiji” 《孔乙己》

“An Incident”《一件小事》

“Storm in a Teacup” 《风波》

“Hometown”《故乡》

“The Rabbits and the Cat” 《兔和猫》

“The Comedy of the Ducks” 《鸭的喜剧》

“Village Opera”《社戏》

"Medicine" 《药》

Critical essay:

“What is Required to be a Father Today” 《我们现在怎样做父亲》

"Preface to Call to Arms" 《〈呐喊〉自序》 
“On the Fall of The Leifeng Pagoda" 《论雷峰塔的倒掉》

“The First and the Last”《最先和最后》

Translation:

"Unfruitful Studious (by Tourumi Yusuke)"

"Father in America (by Arkio Alexander Filander)"

"Father Time (by Eroshenko)"

"The Tragedy of Chicken"

"The Journey in Summer"

"Debate on Law"

"The Method of Reading"

"With Young People"

"My School Life-Fragment (by Eroshenko)"

Academic article: "The Rebuking the Novel in the Late Qing Dynasty"

Among them, the works which most frequently appeared in textbooks were: "The Comedy of the Ducks" (eight times, see fig. 1), "Hometown" (eight times), "The Kite" (seven times), "Autumn Night" (seven times), "The Wise, the Fool and the Flunkey" (five times), "Snow" (four times), and "Medicine" (four times). The rest appeared in different Chinese textbooks at least once or twice. 

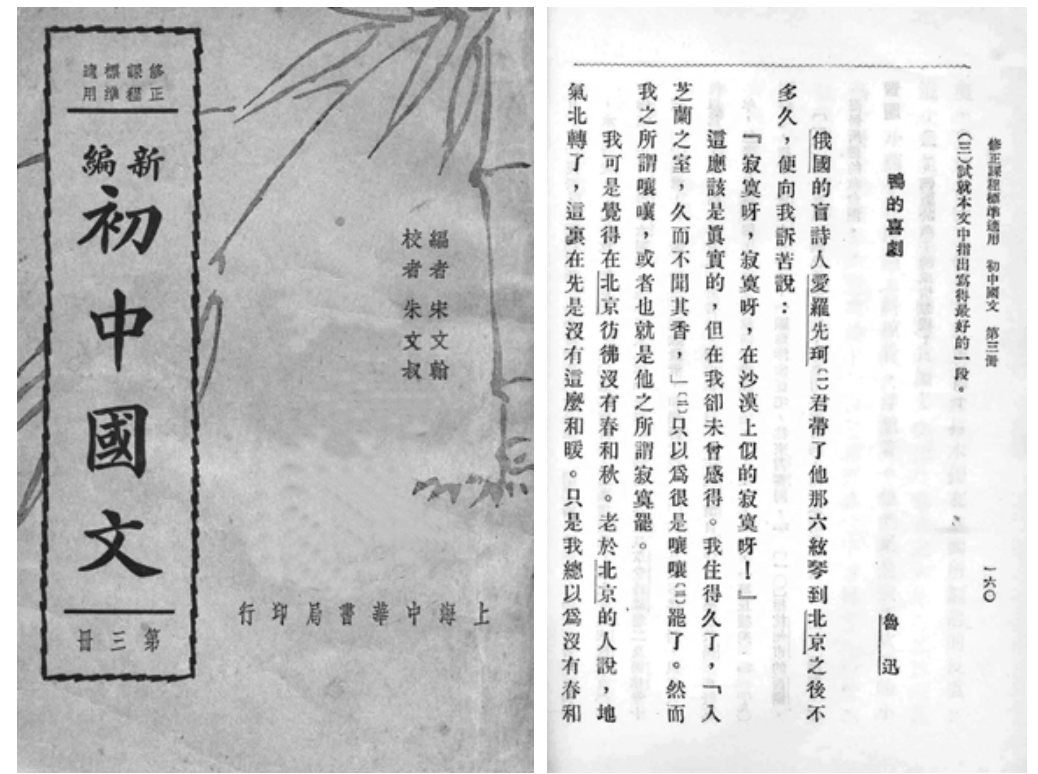

Fig. 1. The page is taken from New Middle School Chinese Textbook in 1938. "The Comedy of the Ducks" is the most popular one.

THE 1920 s -1949

(THE LIBERATED AREAS UNDER THE LEADERSHIP OF THE COMMUNIST PARTY)

Meanwhile, in other areas of China, namely the Central Soviet area, the anti-Japanese base and the liberated areas under the leadership of the Communist Party, the Middle School and High School Chinese textbooks began to be compiled in the mid-1940s. The guidelines for textbook compilation included sections on the training of their own cultural cadres and the need to inspire cooperation with the Agrarian Revolution and Anti-Japanese War.

The Shaanxi-Gansu-Ningxia border region (revolutionary base area) formulated the Middle School Chinese Curriculum Standards (trial) (《初 中国文课程标准草案》) to design Intermediate Chinese Textbook (《中等 国文》） in 1946. The general objective for the textbook stipulated that "all teaching activities of this subject must implement new-democratic revo- 
lution's standpoint and method” (L. Zhang 109). Intermediate Chinese 中等国文》) which was edited by $\mathrm{Hu}$ Qiaomu is the example of this kind of textbook. Mainly, there were textbooks in the Shaanxi-Gansu-Ningxia border region: Chinese Selected Works (《国语文选》) by Li Guangjia in 1948, Middle School Chinese (《初中国文》) by Wang Shisan in 1949 and High School Chinese (《高中国文》) by WanMan et al. in 1949.

Twenty-two of Lu Xun's works were included in the above mentioned textbooks (Li Bin 61), namely:

Story:

“Kong Yiji”《孔乙己》

“An Incident”《一件小事》

“The True Story of Ah Q” 《阿Q正传》 (selected parts)

“Hometown”《故乡》

“The Comedy of the Ducks” 《鸭的喜剧》

“A Madman's Diary” 《狂人日记》

“Village Opera”《社戏》

Critical essay:

"Preface to Linkeduo's Knowledge recorded in the Soviet Union" 《林克多〈苏联见闻录〉序》

“We Will Not be Deceived Any More”《我们不再受骗了》

“Preface of Essays from a Semi-concession”《〈且介亭杂文〉序言》

“On the Postponement of Fair Play” 《论“费厄泼赖”应该缓行》

“Astonishment on the Allied Countries' Behavior”《“友邦惊诧”论》

“Answers for BeiDou Magazine” 《答北斗杂志社问》

“The Rebirth of Chinese” 《中国语文的新生》

“The Opinions on Left-wing Writer Federation” 《对于左翼作家联盟的意见》

“The Abuse and Threat is not Fighting” 《辱骂与恐吓决不是战斗》

“An Illiterate Writer”《不识字的作家》

“The Public are not as Stupid as the Literate Thinks"

《大众并不如读书人所想象的愚蚌》 
“The First and the Last” 《最先与最后》

“Epilogue of Liberated Don Quixote” 《<解放了的唐吉可德>后传》

“How do I Start to Write Novel” 《我怎么做起小说来》

“Rush”《冲》

It is worth noting that it was the first time that "The True Story of Ah Q" was included in the Middle School and High School Chinese textbook.

\subsection{9-1966}

There were several textbook revisions undertaken in accordance with the central government's educational reforms during these 17 years; generally, they can be categorized according to periods.

1949-1955

After the founding of the People's Republic of China, the whole nation was in an enthusiastic mood to create its own national Chinese textbook so as to educate the new citizens under the new era. Thus, the State Administration of the Press nominated the PEP to edit and publish the first set of national Chinese teaching materials which included the Middle School Chinese Textbook (6 volumes) and High School Chinese Textbook (6 volumes) in November 1950. At first, they contained all together 18 of Lu Xun's works.

Later, "The First and the Last," "The Comedy of the Ducks," "The Kite," and "Against Assault" were to be deleted when the State Administration of the Press required the PEP to revise the textbook in 1952. This 1952 version of the textbooks was designed to adapt to the changing demand from the new democratic revolution to the transitional periods of socialist revolution which China had to address at that time. Thus, it focused its attention on the ideological and political aspects of the content but not on Chinese literature and language training. For example, the PEP stated clearly in its Junior Middle School Chinese Textbook (《初级中学语文课本》) that “[e]very subject has the obligation to complete the task of political and ideological education, especially for Chinese subject" (X. Zhang 201). This version of Middle School and High School Chinese textbooks was used until 1955. 
1956-1957

Since Hu Qiaomu, the general secretary of Government Administration Council (the former State Council in China), questioned the problems in Chinese teaching which did not clarify the differences between Chinese language education and literary education. On March 23 1951, several meetings and discussions were conducted by the Political Bureau of the Central Committee of Communist Party of China (CPC) from 1952 to 1954 to study the possibilities of separating Chinese language education and literature education for Middle School and High School. Finally, the decision was made by the Political Bureau of Central Committee of CPC on February 1, 1954 and the People's Education Press was requested to compile a new Chinese textbook and teaching syllabus. This new version of the Middle School and High School Chinese textbooks consisted of two parts: the Chinese language textbook and the Literature textbook. They were launched in the autumn of 1956 on a nationwide scale.

Fourteen of Lu Xun's works were included, namely:

Prose:

“The Wise, the Fool and the Flunkey” 《聪明人和俊子和奴才》

“From Baicao Garden to Three Flavor Study”《从百草园到三味书屋》

“Mr. Fujino” 《藤野先生》

Story: “Kong Yiji” 《孔乙己》

“An Incident”《一件小事》

“Hometown”《故乡》

“Village Opera” 《社戏》

“The New-Year Sacrifice” 《祝福》

"Medicine" 《药》

“Storm in a Teacup”《风波》

Critical Essay:

“For the Oblivious Remembrance" 《为了忘却的记念》

“We Will Not be Deceived Any More”《我们不再受骗了》 
“The Opinions on Left-wing Writer Federation” 《对于左翼作家联盟 的意见》

“On the Fall of the Leifeng Pagoda” 《论雷峰塔的倒掉》

It may be observed that from the list above, there were more literary works by Lu Xun included in the 1954 version than in the 1952 version. The launch of the separate teaching of Chinese Language and Literature in Middle School and High School Chinese textbooks aroused heated discussions. PEP devoted a special column to discuss and present all the opinions about it from 1956-1957. Famous scholars like Lu Dingyi and Zou Yang criticized some aspects of the content of the literature part and the difficult materials of the language teaching part. So a conference was held in December 1956, following Chairman Mao's instruction, in view of producing a simplified Chinese textbook. In March 1958, the decision was made to reconsolidate Chinese language and literature for purposes of unification under the banner of the "Great Leap Forward." So the 1956-1957's version of the Middle School and High School Literature textbooks separating language from literary education was the first and the last version of its kind that ever existed in China.

$1958-1966$

On September 19, 1958, the "Instructions on Educational Work" was promulgated by the Central Committee of the Communist Party of China and the State Council. It stated that "the party's educational policy is to serve the proletarian's political demands, thus necessitating the combination of education and productive labor. In order to implement this policy, educational work must be led by the Party" ("Instructions on Educational Work"). So the PEP rushed to have another version of Middle School and High School Chinese textbooks. There were 10 articles in each book, mainly the works by Mao Zedong and articles about the "Great Leap Forward," "People's Communes," and "China's General Line." Less literary works were selected, including those by Lu Xun. The details are found below (see table 1): 
Table 1. Lu Xun's works in the Middle School and High School Chinese textbooks from 1958 to 1966

\begin{tabular}{|c|c|c|}
\hline Year & Title & Works \\
\hline 1958 & $\begin{array}{l}\text { Middle School } \\
\text { Chinese Textbook }\end{array}$ & $\begin{array}{l}\text { “Kong Yiji” 《孔乙己》 } \\
\text { “From Baicao Garden to Three Flavor Study” } \\
\text { 《从百草园到三味书屋》 } \\
\text { “The Opinions on Left-wing Writer Federation” } \\
\text { 《对于左翼作家联盟的意见》 } \\
\text { “Mr. Fujino"《藤野先生》 }\end{array}$ \\
\hline 1958 & $\begin{array}{l}\text { High School Chi- } \\
\text { nese Textbook }\end{array}$ & 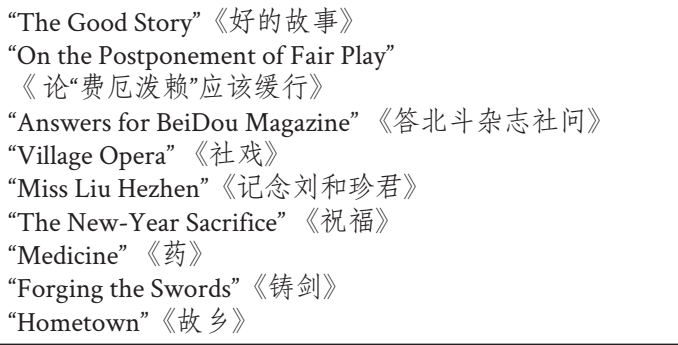 \\
\hline 1960 & $\begin{array}{l}\text { Middle School } \\
\text { Chinese Textbook }\end{array}$ & 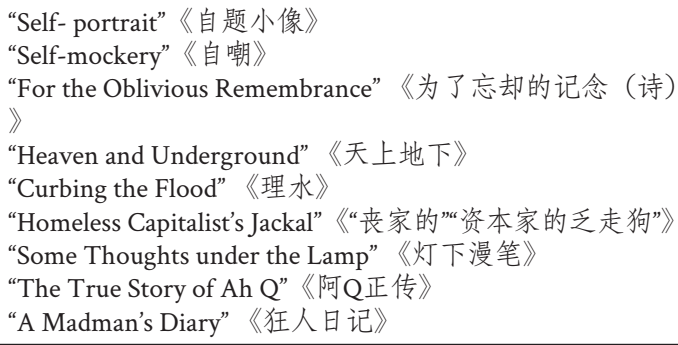 \\
\hline 1960 & $\begin{array}{l}\text { High School Chi- } \\
\text { nese Textbook }\end{array}$ & 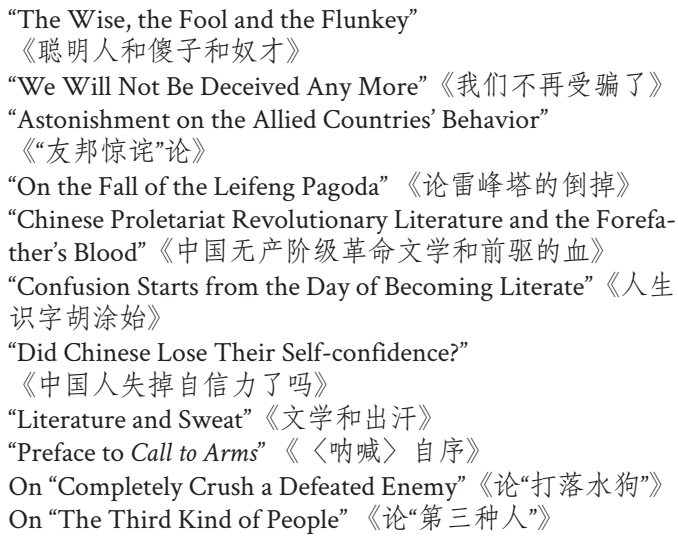 \\
\hline
\end{tabular}


From the list of works in this period as cited above, it may be observed that there was an increase in Lu Xun's critical essays in the Middle School and High School Chinese textbooks during this period.

\subsection{6-1976 (Cultural Revolution)}

To a certain extent, the 33 works listed above prove that Lu Xun was well received by the country, indicating that none of the other literary figures could compete with his status at that time. Later, however, Lu Xun would experience ups and downs during the Cultural Revolution (1966-1976).

On June 13, 1966, the Central Committee of the Communist Party of China and the State Council endorsed a report by the Ministry of Education, "Request for Instructions in the Middle School and High School Politics, Chinese and History Textbook in the 1966-1967 Academic Year.” The new instruction ran contrary to existing ones, as it stated that:

Any textbook that does not assume the leadership of Chairman Mao, does not highlight the proletariat's political characteristics, violates Chairman Mao's theory of class and class struggle, and against the Communist Party's education policy, should henceforth be forbidden. Now the Ministry of Education should organize all the possible forces to reedit the Middle School and High School teaching materials in all the subjects according to the instructions of the Central Committee of the Communist Party and Chairman Mao. (Bo 64)

Thus for the first two or three years of the Cultural Revolution, there were no nationwide Chinese textbooks and even after each province followed the government's proposal to compile their own Chinese textbooks, almost every version of the Middle School and High School Chinese textbooks merely consisted of the works by Mao Zedong, articles praising the contributions of Mao Zedong, and the Cultural Revolution (see the Appendix). It was not until 1968 that the first set of the Middle School and High School Chinese textbooks during the Cultural Revolution was published in Beijing in which Lu Xun's works appeared again. Later, the publication of his works (limited to the essays with strong political relevance) resumed slowly in 1969. Little by little, more and more of his literary works were exempted 
from the prohibition and since 1972, none of Lu Xun's works were banned (L. Wen 5).

According to Gu Zhenbiao (the chief editor of the PEP who has worked there since 1965), during the period of the Cultural Revolution, the Chinese subject was so intertwined with political doctrines and interpretations that it became a kind of "political education" (qtd. in Chang). Furthermore, the efforts in compiling textbooks were all in a mess because almost all the staff members of the PEP were forced to work in the rural areas (due to the Party's intention to transform the intellectuals to become members of the working class). Thus, there were no state-compiled Middle School and High School Chinese textbooks during those ten chaotic years. The textbooks for the Chinese subject were designed according to each province's local demands in line with the central government's policy. Without exception, the "class struggle" and the "two routes struggle" were the main themes of the Chinese textbooks and the main contents were drawn from Chairman Mao's works. Ironically, Lu Xun's works became the only literary materials in Middle School and High School Chinese textbooks because the other writers and their works were banned in the middle and later periods of the Cultural Revolution. Apparently, in this period, at least, the dominant contributor to Lu Xun's canonicity was political rather than "literary" or any other considerations.

During the Cultural Revolution (1966-1976), certain works of Lu Xun were included in the Middle School and High School Chinese Textbooks (see table 2):

Table 2. Lu Xun's works in the Middle School and High School Chinese textbooks from 1966 to 1976

\begin{tabular}{|c|c|c|}
\hline Year & Title & Works \\
\hline 1969 & $\begin{array}{l}\text { The Inner Mon- } \\
\text { golia Autonomous } \\
\text { Region Nine-year } \\
\text { System School } \\
\text { Chinese Textbook } \\
\text { (On Trial) } \\
\text { 《内蒙古自治 } \\
\text { 区九年一贯制 } \\
\text { 学校试用课本 } \\
\text { 语文》 }\end{array}$ & $\begin{array}{l}\text { “Chinese Proletariat Revolutionary Literature and the Forefa- } \\
\text { ther's Blood (included in the } 11^{\text {th }} \text { volume)" } \\
\text { 《中国无产阶级革命文学和前驱的血》 } \\
\text { “On the Postponement of Fair Play”《论“费厄泼赖”应该缓 } \\
\text { 行》(Selected parts in } 13^{\text {th }} \text { volume) }\end{array}$ \\
\hline
\end{tabular}




\begin{tabular}{|c|c|c|}
\hline 1969 & $\begin{array}{l}\text { Beijing Middle } \\
\text { School and High } \\
\text { School Chinese } \\
\text { Textbook (Trial } \\
\text { Version) } \\
\text { 《北京市中学 } \\
\text { 试用课本语 } \\
\text { 文》 }\end{array}$ & $\begin{array}{l}\text { “Answers for Bei Dou Magazine" 《答北斗杂志社问》（in- } \\
\text { cluded in the } 2^{\text {nd }} \text { volume) } \\
\text { “Astonishment on the Allied Countries' Behavior" } \\
\text { 《“友邦惊诧”论》 (included in the } 4^{\text {th }} \text { volume) } \\
\text { “Literature and Sweat" (included in the } 4^{\text {th }} \text { volume) } \\
\text { 《文学和出汗》 } \\
\text { "A Reply to the Trotskyists” 《答托洛斯基派的信》(included } \\
\text { in the } 5^{\text {th }} \text { volume) } \\
\text { “Untitled" 《无题》(included in the } 5^{\text {th }} \text { volume) } \\
\text { “Self-mockery” 《自嘲》(included in the } 5^{\text {th }} \text { volume) }\end{array}$ \\
\hline $1972-1975$ & $\begin{array}{l}\text { Beijing Middle } \\
\text { School and High } \\
\text { School Chinese } \\
\text { Textbook } \\
\text { 《北京市中学 } \\
\text { 课本语文》 }\end{array}$ & 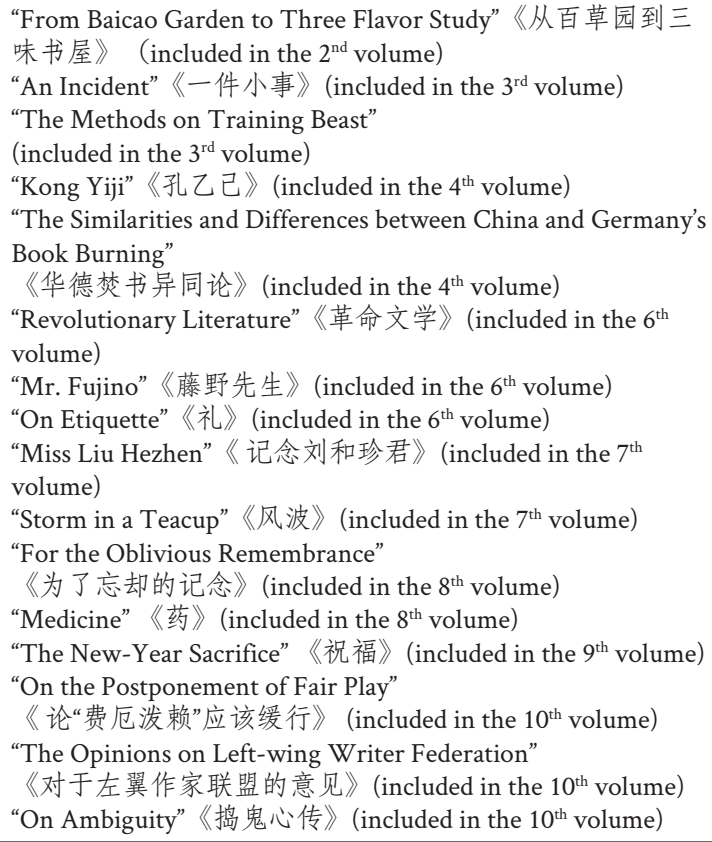 \\
\hline 1973 & $\begin{array}{l}\text { Gangsu Middle } \\
\text { School Chinese } \\
\text { Textbook (Trial } \\
\text { Version) } \\
\text { 《甘肃省初中 } \\
\text { 试用语文课 } \\
\text { 本》 }\end{array}$ & $\begin{array}{l}\text { "A Real Letter" 《一封真实的信》 } \\
\text { "The Preface for Bai Mang's Haier Ta" } \\
\text { 《白莽作 (孩儿塔) 序》 }\end{array}$ \\
\hline 1973 & $\begin{array}{l}\text { Gangsu High } \\
\text { School Chinese } \\
\text { Textbook (Trial } \\
\text { Version) } \\
\text { 《甘肃省高中 } \\
\text { 试用语文课 } \\
\text { 本》 }\end{array}$ & $\begin{array}{l}\text { "Confucius in Modern China" } \\
\text { 《在现代中国的孔夫子》 }\end{array}$ \\
\hline
\end{tabular}




\begin{tabular}{|c|c|c|}
\hline $\begin{array}{l}1973 \\
-1976\end{array}$ & $\begin{array}{l}\text { Jilin Middle } \\
\text { School Chinese } \\
\text { Textbook (Trial } \\
\text { Version) } \\
\text { 《吉林省初中 } \\
\text { 试用语文课 } \\
\text { 本》 }\end{array}$ & $\begin{array}{l}\text { “Reply Xu Maoyong and on Question about } \\
\text { Anti-Japanese United Front" } \\
\text { 《答徐惁庸并关于抗日统一战线问题》 } \\
\text { “Kong Yiji”《孔己》 } \\
\text { “Custom and Reform”《习惯与改革》 } \\
\text { “Abortion and Sterilization”《流产与断种》 }\end{array}$ \\
\hline $\begin{array}{l}1973 \\
-1976\end{array}$ & $\begin{array}{l}\text { Tianjin Middle } \\
\text { School and High } \\
\text { School Chinese } \\
\text { Textbook (Trial } \\
\text { Version) } \\
\text { 《天津市中学 } \\
\text { 试用语文课 } \\
\text { 本》 }\end{array}$ & $\begin{array}{l}\text { “Hometown” 《故乡》 } \\
\text { "Some Metaphors" 《一点比喻》 } \\
\text { "March Time's the Leased Territory" 《三月的租界》 }\end{array}$ \\
\hline 1973 & $\begin{array}{l}\text { Tianjin Middle } \\
\text { School Chinese } \\
\text { Textbook(Trial } \\
\text { Version) } \\
\text { 《天津市初中 } \\
\text { 试用课本语 } \\
\text { 文》 }\end{array}$ & $\begin{array}{l}\text { "Village Opera" 《社戏》 } \\
\text { (volume one for Grade Two) }\end{array}$ \\
\hline $\begin{array}{l}1972 \\
-1973\end{array}$ & $\begin{array}{l}\text { The Inner Mon- } \\
\text { golia Autonomous } \\
\text { Region Middle } \\
\text { School and High } \\
\text { School Chinese } \\
\text { Textbook (Trial } \\
\text { Version) } \\
\text { 《内蒙古自治 } \\
\text { 区中学试用课 } \\
\text { 本语文》 }\end{array}$ & $\begin{array}{l}\text { “Preface of My Collection” 《(自选集)自序》(the } 6^{\text {th }} \text { volume) } \\
\text { “An Impromptu Composition”《偶成》(the } 6^{\text {th }} \text { volume) } \\
\text { “Did Chinese Lose Their Self-confidence?” } \\
\text { 《中国人失掉自信力了吗》(the } 6^{\text {th }} \text { volume) } \\
\text { “The Abuse and Threaten is not Fighting” } \\
\text { 《辱骂与恐吓决不是战斗》(the } 8^{\text {th }} \text { volume) } \\
\text { “Preface of the Miscellany in Qiejieting” } \\
\text { 《(且介亭杂文)序言》(the } 9^{\text {th }} \text { volume) }\end{array}$ \\
\hline $\begin{array}{l}1974 \\
-1975\end{array}$ & $\begin{array}{l}\text { The Inner Mon- } \\
\text { golia Autonomous } \\
\text { Region Middle } \\
\text { School and High } \\
\text { School Chinese } \\
\text { Textbook (Trial } \\
\text { Version) } \\
\text { 《内蒙古自治 } \\
\text { 区中学试用课 } \\
\text { 本语文》 }\end{array}$ & $\begin{array}{l}\text { "Small Talks in Late Spring”《春末闲谈》 } \\
\text { (volume two for Middle School Grade Two) } \\
\text { "Celebrate Shanghai-Nanjing Retake the Other Side" } \\
\text { 《庆祝沪宁克复的那一边》 } \\
\text { (volume two for High School) } \\
\text { "Revenge"《算账》 (volume two for High School) }\end{array}$ \\
\hline
\end{tabular}




\begin{tabular}{|c|c|c|}
\hline 1972 & $\begin{array}{l}\text { Shanghai Middle } \\
\text { School and High } \\
\text { School Chinese } \\
\text { Textbook } \\
\text { 《上海市中学 } \\
\text { 课本语文》 }\end{array}$ & $\begin{array}{l}\text { "Some Trivial Thoughts on Reading (the second parts)" } \\
\text { 一年级第二学期用: 《看书琐记(二)》 } \\
\text { (the } 2^{\text {nd }} \text { semester of Grade One) } \\
\text { "On the Benevolent Thinking in China" } \\
\text { 《关于中国的王道》(the } 2^{\text {nd }} \text { semester of Grade Three) } \\
\text { "Some Stories of Zhang Taiyang”《关于太炎先生二三事》 } \\
\text { (the } 1^{\text {st }} \text { semester of Grade Four) }\end{array}$ \\
\hline 1972 & $\begin{array}{l}\text { Hubei High } \\
\text { School Chinese } \\
\text { Textbook (Trial } \\
\text { Version) } \\
\text { 《湖北省高中 } \\
\text { 试用课本语 } \\
\text { 文》 }\end{array}$ & $\begin{array}{l}\text { "Ode to the Goddess of the Xiang River" } \\
\text { 《湘灵歌》 (included in } 1^{\text {st }} \text { volume) }\end{array}$ \\
\hline 1975 & $\begin{array}{l}\text { Hubei Middle } \\
\text { School Chinese } \\
\text { Textbook (Trial } \\
\text { Version)《湖北 } \\
\text { 省初中试用课 } \\
\text { 本语文》 }\end{array}$ & $\begin{array}{l}\text { “Do not Know the Taste of Meat and Water (On Concentra- } \\
\text { tion)" } \\
\text { 《不知肉味和不知水味》(included in } 3^{\text {rd }} \text { volume) }\end{array}$ \\
\hline 1974 & $\begin{array}{l}\text { Fujian Middle } \\
\text { School and High } \\
\text { School Chinese } \\
\text { Textbook 《福建 } \\
\text { 省中学课本语 } \\
\text { 文》 }\end{array}$ & $\begin{array}{l}\text { "Fourteen-year's “Classical Works Reading”" } \\
\text { 《十四年的“读经”》(the } 1^{\text {st }} \text { volume of High School Grade } \\
\text { One) }\end{array}$ \\
\hline 1975 & $\begin{array}{l}\text { Fujian Middle } \\
\text { School and High } \\
\text { School Chinese } \\
\text { Textbook (Trial } \\
\text { Version)《福建 } \\
\text { 省中学试用课 } \\
\text { 本语文》 }\end{array}$ & $\begin{array}{l}\text { "Death (selected parts)" } \\
\text { 《死》(节选) (the } 1^{\text {st }} \text { volume of Grade Two) }\end{array}$ \\
\hline 1972 & $\begin{array}{l}\text { Jiangsu Middle } \\
\text { School and High } \\
\text { School Chinese } \\
\text { Textbook (Trial } \\
\text { Version) 《江苏 } \\
\text { 省中学试用课 } \\
\text { 本语文》 }\end{array}$ & $\begin{array}{l}\text { “Difficult Questions” } \\
\text { 《难答的问题》(选自《且介亭杂文末编》) } \\
\text { (the } 1^{\text {st }} \text { volume of Middle School Grade One) }\end{array}$ \\
\hline 1974 & $\begin{array}{l}\text { Jiangsu Middle } \\
\text { School and High } \\
\text { School Chinese } \\
\text { Textbook 《江苏 } \\
\text { 省中学课本语 } \\
\text { 文》 }\end{array}$ & $\begin{array}{l}\text { “The Old Tune has Already Finished-The Speech at Hong } \\
\text { Kong Youth Men's Christian Association on February 29, } 1927 \text { " } \\
\text { 《老调子已经唱完-- 一九二七年二月二十九日在香港青年 } \\
\text { 会上讲》(the } 9^{\text {th }} \text { volume) }\end{array}$ \\
\hline
\end{tabular}




\begin{tabular}{|c|c|c|}
\hline 1972 & $\begin{array}{l}\text { Hebei High School } \\
\text { Chinese Textbook } \\
\text { (Trial Version)《 } \\
\text { 河北省高中试 } \\
\text { 用课本语文》 }\end{array}$ & $\begin{array}{l}\text { “Confusion Starts from the Day of Becoming Literate" 《人生识 } \\
\text { 字胡涂始》( the } 3^{\text {rd }} \text { volume) }\end{array}$ \\
\hline 1976 & $\begin{array}{l}\text { Hebei Middle } \\
\text { School and High } \\
\text { School Chinese } \\
\text { Textbook (Trial } \\
\text { Version)《河北 } \\
\text { 省中学试用课 } \\
\text { 本语文》 }\end{array}$ & “Illiterate Writer"《不识字的作家》(the $2^{\text {nd }}$ volume) \\
\hline 1975 & $\begin{array}{l}\text { Liaoning Middle } \\
\text { School and High } \\
\text { School Chinese } \\
\text { Textbook (Trial } \\
\text { Version)《辽宁 } \\
\text { 省中学试用课 } \\
\text { 本语文》 }\end{array}$ & $\begin{array}{l}\text { "The Changes of Hooligan" 《流讯的变迁》(included in the } \\
6^{\text {th }} \text { volume) }\end{array}$ \\
\hline 1970 & $\begin{array}{l}\text { Liaoning Middle } \\
\text { School Chinese } \\
\text { Textbook (Trial } \\
\text { Version)《辽宁 } \\
\text { 省初中语文实 } \\
\text { 验教材》 }\end{array}$ & “Self- Portrait"《自题小像》(included in the $1^{\text {st }}$ volume) \\
\hline $\begin{array}{l}1971 \\
-1977\end{array}$ & $\begin{array}{l}\text { Qinghai Middle } \\
\text { School and High } \\
\text { School Chinese } \\
\text { Textbook (Trial } \\
\text { Version) 《青海 } \\
\text { 省中学试用课 } \\
\text { 本语文》 }\end{array}$ & $\begin{array}{l}\text { “Kite” 《风笔》(the } 2^{\text {nd }} \text { volume for Grade Two) } \\
\text { "Warrior and Fly" } \\
\text { 《战士和苍蝇》(the } 2^{\text {nd }} \text { volume for Grade Four) }\end{array}$ \\
\hline 1975 & $\begin{array}{l}\text { Guangdong } \\
\text { Middle School } \\
\text { and High School } \\
\text { Chinese Textbook } \\
\text { (Trial Version) 《 } \\
\text { 广东省中学试 } \\
\text { 用课本语文》 }\end{array}$ & $\begin{array}{l}\text { “To Tai Jingnong" 《致台静农》 } \\
\text { (the } 1^{\text {st }} \text { semester of Midddle School Grade Two) }\end{array}$ \\
\hline 1974 & $\begin{array}{l}\text { Yunnan High } \\
\text { School Chinese } \\
\text { Textbook (Trial } \\
\text { Version)《云南 } \\
\text { 省高中试用课 } \\
\text { 本语文》 }\end{array}$ & $\begin{array}{l}\text { "Before the Birth of the Talent" } \\
\text { 《未有天才之前》(included in the } 3^{\text {rd }} \text { volume) }\end{array}$ \\
\hline
\end{tabular}

Source: Zhou Haiying and Zhou Lingfei. "What are Lu Xun's works in Primary, Middle and High School Chinese Textbooks?" Digest of Chinese and Foreign Books, vol. 1, 2012. 
It is interesting to note that certain works by Lu Xun which were included in the textbooks during this period did not appear again in subsequent periods, suggesting that the inclusion of the works was mainly meant to serve political and ideological purposes. Examples are: "Revolutionary Literature," "Reply Xu Maoyong and on Question about Anti-Japanese United Front," "The Abuse and Threaten is not Fighting," and "The Changes of Hooligan."

\subsection{7-1999}

After the dark ten years for ordinary intellectuals which were a bright time for Lu Xun, China finally struggled to be free from "class struggle" and began to focus on the country and its citizens' real development. The Ministry of Education organized the educational experts and scholars to edit the primary and secondary school teaching materials in September 1977 and issued one set of a trial version in the autumn of 1978. This trial version was revised in 1980 and finally launched nationally in 1982. From then on, the process of establishing the Chinese teaching material system was gradually completed.

According to $\mathrm{Gu}$ Zhenbiao who attended to the editing and revision of all the Chinese textbooks after the Cultural Revolution, "although the Cultural Revolution was over, there were many historical problems which had not yet been clarified, such as the issue of the 'rehabilitation' of many intellectuals and writers, who were still waiting for their reputation to be rehabilitated; so Lu Xun became the first choice to be included into the Chinese textbooks" (Chang Lei).

Thus, Lu Xun's works were included in the unified national Chinese Middle School and High School textbooks again to meet a different time's demands. From then on, Lu Xun, the writer, would find himself constructed somewhere in the intersection between state intervention and modern literary and cultural criticism, constituting "Lu Xun," the cultural and political figure in China. On the one hand, the country needed the "spirit" to encourage the Chinese to face the future courageously; on the other hand, 
the experience of relative freedom in the academic world enabled the scholars to closely study Lu Xun and interpret his works more freely.

Since the central government appointed the PEP as the main textbook publisher again, almost the whole country's Middle Schools and High Schools used their version from 1977 to 1999 . The changes in the representation of Lu Xun's works during this period are notable.

Altogether, 25 articles in these three versions of the Chinese Middle School and High School textbooks by the PEP appeared from 1977 to 1999. These included the following works by Lu Xun:

Prose:

“Miss Liu Hezhen”《记念刘和珍君》

“From Baicao Garden to Three Flavor Study”《从百草园到三味书屋》

“Fan Ainong”《范爱农》

“Snow”《雪》

“The Kite”《风筆》

“Mr. Fujino”《藤野先生》

“For the Oblivious Remembrance"《为了忘却的记念》

Story:

“A Madman's Diary” 《狂人日记》

“Kong Yiji” 《孔乙己》

"Medicine" 《药》

“An Incident”《一件小事》

“Hometown”《故乡》

“The True Story of Ah Q” 《阿Q正传》

"Village Opera” 《社戏》

“The New-Year Sacrifice”《祝福》

Critical Essay:

“Preface to Call to Arms” 《〈呐喊〉自序》

“On the Fall of The Leifeng Pagoda”《论雷峰塔的倒掉》

“Literature and Sweat”《文学和出汗》 
“On the Postponement of Fair Play” 《论“费厄泼赖”应该缓行》

“Astonishment on the Allied Countries' Behavior”《“友邦惊诧”论》

“Grabbism”《拿来主义》

“Did Chinese Lose Their Self-confidence?” 《中国人失掉自信力了吗》

“Answers for Bei Dou Magazine” 《答北斗杂志社问》

“Confusion Starts from the Day of Becoming Literate”《人生识字胡 涂始》

Biography:

“Autobiography of Lu Xun”《鲁迅自传》

To be noted in the list are some slight changes, such as the removal of "The Kite" and "Snow" after the 1981 Middle School Chinese version; but apart from these, $\mathrm{Lu}$ Xun's works that were included in the three versions of the Middle School Chinese textbooks (1978, 1987, and 1992) were almost the same. However, in the High School Chinese textbooks (1980, 1987, and 1992), there were comparatively big changes. "A Madman's Diary," for example, was not included in any version of the High School Chinese textbooks after 1982. Also, worth noting is the addition of "Fan Ainong," "Grabbism," and "Autobiography of Lu Xun" which were included in the PEP's Chinese Middle School and High School textbooks during this period. "On the Postponement of Fair Play" first appeared in the 1987 High School Chinese version.

\subsection{0-2017}

In the 1980s and the 1990s, with the opening up and deepening of reforms, the Chinese government rapidly developed the country's economic productivity and efficiency. In response to the rapid social and economic development, a drastic reform of the educational system was announced in 1985 (Lewin et al. 3). Firstly, the nine-year compulsory education law was promulgated in 1986; then followed the decentralization of educational administration which allowed regional agencies to compete with the PEP in the publication of textbooks and references in accordance with different 
regional needs. Furthermore, the Chinese education ministry issued "The Fundamental Education Curriculum Reform Outline” in 2001 in order to cultivate well-rounded citizens in the new millennium.

In the midst of all these reforms, the Middle School and High School Chinese textbooks in the 1990s could not meet the needs of the time. Increasingly, negative comments were expressed about the outdated contents of the Chinese teaching materials. The feedback from the students and the educational world urged the PEP to develop the new Middle School and High School Chinese textbooks in 1996. After several years of trial, because of the positive responses from the provinces like Jiangxi, Shanxi, and Tianjin, the Ministry of Education decided to recommend at the end of 1999 the new set of Middle School and High School Chinese textbooks to the schools throughout the country. So officially, the whole of China began to use the new version of the Middle School and High School Chinese textbooks in the fall of 2000 .

There were mainly three versions of the Middle School Chinese textbooks during this period, which were issued in 2001, 2007, and 2011. The details are found in the lists below (see tables 3 and 4):

Table 3. Lu Xun's works in the 2001 version of the Middle School Chinese textbooks

\begin{tabular}{|c|c|c|}
\hline Year & Name & Works \\
\hline 2001 & $\begin{array}{l}\text { Middle School } \\
\text { Chinese } \\
\text { (the } 1^{\text {st }} \text { volume) }\end{array}$ & $\begin{array}{l}\text { "From Baicao Garden to Three Flavor Study" } \\
\text { 《从百草园到三味书屋》 }\end{array}$ \\
\hline 2001 & $\begin{array}{l}\text { Middle School } \\
\text { Chinese } \\
\text { (the } 2^{\text {nd }} \text { volume) }\end{array}$ & "Village Opera" 《社戏》 \\
\hline 2001 & $\begin{array}{l}\text { Middle School } \\
\text { Chinese } \\
\text { (the } 3^{\text {rd }} \text { volume) }\end{array}$ & $\begin{array}{l}\text { "A Chang and Chinese Bestiary" } \\
\text { 《阿长与〈山海经〉》 }\end{array}$ \\
\hline 2001 & $\begin{array}{l}\text { Middle School } \\
\text { Chinese } \\
\text { (the } 4^{\text {th }} \text { volume) }\end{array}$ & “Autobiography of Lu Xun” 《鲁迅自传》 \\
\hline 2001 & $\begin{array}{l}\text { Middle School } \\
\text { Chinese } \\
\text { (the } 5^{\text {th }} \text { volume) }\end{array}$ & $\begin{array}{l}\text { "Hometown”《故乡》 } \\
\text { “Did Chinese Lose Their Self-confidence?" } \\
\text { 《中国人失掉自信力了吗》 }\end{array}$ \\
\hline
\end{tabular}




\begin{tabular}{|l|l|l|}
\hline 2001 & $\begin{array}{l}\text { Middle School } \\
\text { Chinese } \\
\text { (the } 6^{\text {th }} \text { volume) }\end{array}$ & $\begin{array}{l}\text { “Mr. Fujino” 《藤野先生》 } \\
\text { “Kong Yiji” 《记乙巳》 }\end{array}$ \\
\hline
\end{tabular}

Table 4. Lu Xun's works in the 2007 version of the Middle School Chinese textbooks

\begin{tabular}{|c|c|c|}
\hline Year & Name & Works \\
\hline 2007 & $\begin{array}{l}\text { Chinese (Grade } \\
\text { Seven } 1^{\text {st }} \text { vol- } \\
\text { ume) }\end{array}$ & “The Kite” 《风筝》 \\
\hline 2007 & $\begin{array}{l}\text { Chinese (Grade } \\
\text { Seven } 2^{\text {nd }} \\
\text { volume) }\end{array}$ & $\begin{array}{l}\text { “From Baicao Garden to Three Flavor Study”《从百草园到三 } \\
\text { 味书屋》 } \\
\text { “Village Opera”《社戏》 }\end{array}$ \\
\hline 2008 & $\begin{array}{l}\text { Chinese (Grade } \\
\text { Eight } 1^{\text {st }} \text { vol- } \\
\text { ume) }\end{array}$ & $\begin{array}{l}\text { "A Chang and Chinese Bestiary" } \\
\text { 《阿长与〈山海经〉》 }\end{array}$ \\
\hline 2008 & $\begin{array}{l}\text { Chinese (Grade } \\
\text { Eight } 2^{\text {nd }} \text { vol- } \\
\text { ume) }\end{array}$ & $\begin{array}{l}\text { “Mr. Fujino"《藤野先生》 } \\
\text { “Snow" 《雪》 }\end{array}$ \\
\hline 2009 & $\begin{array}{l}\text { Chinese (Grade } \\
\text { Nine } 1^{\text {st }} \text { vol- } \\
\text { ume) }\end{array}$ & $\begin{array}{l}\text { “Hometown”《故乡》 } \\
\text { “Did Chinese Lose Their Self-confidence?” } \\
\text { 《中国人失掉自信力了吗》 }\end{array}$ \\
\hline 2009 & $\begin{array}{l}\text { Chinese (Grade } \\
\text { Nine } 2^{\text {nd }} \text { vol- } \\
\text { ume) }\end{array}$ & “Kong Yiji” 《孔乙己》 \\
\hline
\end{tabular}

There were two versions of the High School Chinese textbooks during this period, issued in 2003 and 2007. The details are found in the lists below (see tables 5 and 6):

Table 5. Lu Xun's works in the 2003 version of the High School Chinese textbooks

\begin{tabular}{|l|l|l|}
\hline Year & Name & Works \\
\hline $\begin{array}{l}\text { June } \\
2003\end{array}$ & $\begin{array}{l}\text { Full-time High } \\
\text { School Chinese } \\
\text { (the } 1^{\text {st }} \text { volume) }\end{array}$ & “Preface to Call to Arms" 《〈呐喊〉自序口 \\
\hline & $\begin{array}{l}\text { Full-time High } \\
\text { School Chinese } \\
\text { (the } 2^{\text {nd }} \text { volume) }\end{array}$ & $\begin{array}{l}\text { “The New-Year Sacrifice"《祝福》 } \\
\text { “Grabbism"《拿来主义》 }\end{array}$ \\
\hline
\end{tabular}




\begin{tabular}{|l|l|l|}
\hline & $\begin{array}{l}\text { Full-time High } \\
\text { School Chinese } \\
\text { (the } 3^{\text {rd }} \text { volume) }\end{array}$ & $\begin{array}{l}\text { "Miss Liu Hezhen” 《记念刘和珍君》 } \\
\text { “Some Thoughts under the Lamp" 《灯下漫笔》 }\end{array}$ \\
\hline $\begin{array}{l}\text { Full-time High } \\
\text { School Chinese } \\
\text { (the } 4^{\text {th }} \text { volume) }\end{array}$ & "Medicine" 《药》 \\
\hline $\begin{array}{l}\text { Full-time High } \\
\text { School Chinese } \\
\text { (the } 5^{\text {th }} \text { volume) }\end{array}$ & "The True Story of Ah Q" 《阿Q正传》 \\
\hline
\end{tabular}

Table 6. Lu Xun's works in the 2007 version of the High School Chinese textbooks in accordance with the New Curriculum Standard

\begin{tabular}{|l|l|l|}
\hline Year & Name & Works \\
\hline 2007 & $\begin{array}{l}\text { New Curriculum } \\
\text { Standard High } \\
\text { School Chinese } \\
\text { (One) }\end{array}$ & “Miss Liu Hezhen"《记念刘和珍君》 \\
\hline & $\begin{array}{l}\text { New } \text { Curriculum } \\
\text { Standard High } \\
\text { School Chinese } \\
\text { (Two) }\end{array}$ & \\
\hline & $\begin{array}{l}\text { New Curriculum } \\
\text { Standard High } \\
\text { School Chinese } \\
\text { (Three) }\end{array}$ & “The New-Year Sacrifice" 《祝福》 \\
\hline & $\begin{array}{l}\text { New Curriculum } \\
\text { Standard High } \\
\text { School Chinese } \\
\text { (Four) }\end{array}$ & \\
\hline & $\begin{array}{l}\text { New Curriculum } \\
\text { Standard High } \\
\text { School Chinese } \\
\text { (Five) }\end{array}$ & \\
\hline
\end{tabular}

From 2000 to 2008, there were 17 works by Lu Xun in the above-mentioned Middle School and High School Chinese textbooks, namely: 
Prose:

“Snow” 《雪》

“The Kite”《风笔》

“A Chang and 'Chinese Bestiary” 《阿长与〈山海经〉》

“From Baicao Garden to Three Flavor Study”《从百草园到三味书屋》

“Miss Liu Hezhen”《记念刘和珍君》

“Autobiography of Lu Xun” 《鲁迅自传》

“Mr. Fujino”《藤野先生》

Story:

“Kong Yiji”《孔乙已》

"Medicine" 《药》

“Hometown”《故乡》

“The True Story of Ah Q” 《阿Q正传》

“Village Opera” 《社戏》

“The New-Year Sacrifice”《祝福》

Critical essay:

“Some Thoughts under the Lamp” 《灯下漫笔》

“Grabbism”《拿来主义》

“Did Chinese Lose Their Self-confidence?” 《中国人失掉自信力了吗》

“Preface to Call to Arms” 《〈呐喊〉自序》

The PEP version of compulsory education textbooks (hereafter referred to as the new textbooks) were revised and improved based on the new curriculum standards for compulsory education subjects (2011 edition). It was promulgated by the Ministry of Education, based on more than ten years of textbook experiments and follow-up researches. It is the eleventh set of primary and secondary school textbooks compiled and published by the PEP. The new textbooks implement the spirit of the "National Medium and Long-term Educational Reform and Development Plan (2010-2020),” uphold the concept of quality education, follow the fundamental principles 
of moral education first and aim to educate people next, and fully absorb the experience of the new curriculum reform.

Table 7. Lu Xun's works in the 2011 version of the Middle School Chinese textbooks in accordance with the New Curriculum Standard

\begin{tabular}{|c|c|c|}
\hline Year & Name & Works \\
\hline 2011 & $\begin{array}{l}\text { Chinese (Grade } \\
\text { Seven } 1^{\text {st }} \\
\text { volume) }\end{array}$ & \\
\hline 2011 & $\begin{array}{l}\text { Chinese (Grade } \\
\text { Seven } 2^{\text {nd }} \\
\text { volume) }\end{array}$ & $\begin{array}{l}\text { “From Baicao Garden to Three Flavor Study" 《从百草园到三 } \\
\text { 味书屋》 } \\
\text { “Village Opera”《社戏》 }\end{array}$ \\
\hline 2011 & $\begin{array}{l}\text { Chinese (Grade } \\
\text { Eight } 1^{\text {st }} \text { vol- } \\
\text { ume) }\end{array}$ & $\begin{array}{l}\text { "A Chang and Chinese Bestiary" } \\
\text { 《阿长与〈山海经〉》 }\end{array}$ \\
\hline 2011 & $\begin{array}{l}\text { Chinese (Grade } \\
\text { Eight } 2^{\text {nd }} \text { vol- } \\
\text { ume) }\end{array}$ & $\begin{array}{l}\text { “Mr. Fujino”《藤野先生》 } \\
\text { "Snow" 《雪》 }\end{array}$ \\
\hline 2011 & $\begin{array}{l}\text { Chinese (Grade } \\
\text { Nine } 1^{\text {st }} \text { vol- } \\
\text { ume) }\end{array}$ & $\begin{array}{l}\text { "Hometown”《故乡》 } \\
\text { "Did Chinese Lose Their Self-confidence?" } \\
\text { 《中国人失掉自信力了吗》 }\end{array}$ \\
\hline 2011 & $\begin{array}{l}\text { Chinese (Grade } \\
\text { Nine } 2^{\text {nd }} \text { vol- } \\
\text { ume) }\end{array}$ & “Kong Yiji” 《孔乙己》 \\
\hline
\end{tabular}

Table 8. Lu Xun's works in the 2011 version of the High School Chinese textbooks in accordance with the New Curriculum Standard

\begin{tabular}{|l|l|l|}
\hline Year & Name & Works \\
\hline 2011 & $\begin{array}{l}\text { New } \text { Curriculum } \\
\text { Standard High } \\
\text { School Chinese } \\
\text { (One) }\end{array}$ & “Miss Liu Hezhen" 《记念刘和珍君》 \\
\hline & $\begin{array}{l}\text { New } \text { Curriculum } \\
\text { Standard High } \\
\text { School Chinese } \\
\text { (Two) }\end{array}$ & \\
\hline & $\begin{array}{l}\text { New Curriculum } \\
\text { Standard High } \\
\text { School Chinese } \\
\text { (Three) }\end{array}$ & “The New-Year Sacrifice" 《祝福》 \\
\hline
\end{tabular}




\begin{tabular}{|l|l|l|}
\hline & $\begin{array}{l}\text { New } \text { Curriculum } \\
\text { Standard High } \\
\text { School Chinese } \\
\text { (Four) }\end{array}$ & \\
\hline & $\begin{array}{l}\text { New } \text { Curriculum } \\
\text { Standard High } \\
\text { School Chinese } \\
\text { (Five) }\end{array}$ & \\
\hline
\end{tabular}

Notable in the above lists is the apparent reduction in the number of $\mathrm{Lu}$ Xun's works represented in the Chinese textbooks from 2000 to 2011.

Except for "The Kite" which was altogether taken out of the Chinese textbook in 2011, there has not been so much adjustment in Lu Xun's works which have been included in the Middle School Chinese textbooks since 2010. However, Lu Xun's works in the High School Chinese textbooks were sharply reduced.

Since the 2011 version of the Middle School Chinese textbooks was launched in accordance with the requirements of the new curriculum standard, combined with feedback on the problems found in the experiments, and based on reasonable suggestions, the 2017 PEP version of the compulsory education textbooks (hereafter referred to as the new textbook) has been revised again. The revised principle requires that "the selection of essays should be classics, and meet the age needs of students, suitable for teaching." Although the PEP has revised the Middle School Chinese textbooks, Lu Xun's works have not changed compared with the 2011 version in the 2017 Middle School Chinese textbooks.

Currently, there are only 8 works by Lu Xun that are still in the Middle School Chinese textbooks and 3 left in the High School Chinese textbooks. Thus, canonicity in the case of Lu Xun, can be said to have been caught by the whirlwinds of Chinese history, his status in the literary canon of China being rather unstable. Such is all that is left of Lu Xun in the Chinese textbooks, a far cry from the Lu Xun of the early $20^{\text {th }}$ century and the heady days of the Chinese Revolution. 


\section{Appendix}

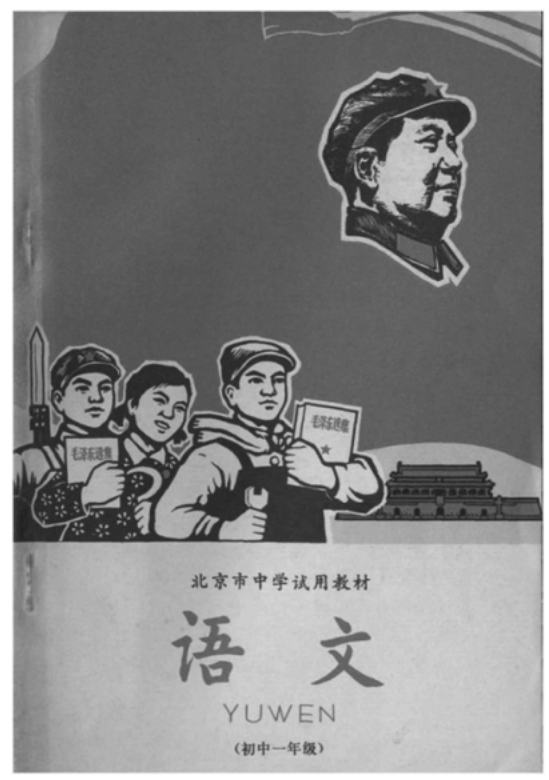

The cover page
我们的数育方针, 应该使受数育 者在德育、督育、休育几方面都得到 发展, 成为有社会主义觉悟的有文化 的劳动者。

学生也是这样, 以学为主, 兼学 别样, 即不但学文, 也要学工、学农、 学军, 也要批判资产阶级。学制要缩 短, 教育要革命, 资产阶级知识分子 统治我们学校的现象, 再也不能纸续 下去了。

进行无产阶级救育革命, 要依洜 学校中广大革命的学生, 革命的教员, 革命的工人，要依垔他们中间的积极 分子, 即决心把无产阶级文化大革命 进行到底的无产阶级革命派。

\section{少调东}

The First Set of Middle School and High School Chinese Textbooks during the Cultural Revolution in April 1968

Source: Extracts from the first set of middle school and high school textbooks. Chinese Posters, chineseposters.net/themes/luxun, https:// epaper.gmw.cn/zhdsb/html/2015-05/27/ nw.D110000zhdsb_20150527_1-05.htm?div=-1. JPEG file. Accessed on 27 July 2020. 


\section{Notes}

1. Classical Chinese (文言文) is a written form of Old Chinese modeled on the classical language which is different from any modern spoken form of Chinese. It was used in almost all formal writing in China until the early $20^{\text {th }}$ century when it was replaced by vernacular written Chinese. Conciseness and compactness are the general features of Classical Chinese. Vernacular Chinese (白话) was developed on the basis of the varieties of Chinese spoken language and the written form of Vernacular Chinese based on Mandarin Chinese, so that the ordinary Chinese could become literate.

2. In Chinese, "chetui" means a condition of having to move backward to find the shelter; here I use the word "retreat" to describe the situation of Lu Xun's works in Chinese textbooks in the 21st century. Since the number of his works keeps decreasing, it looks like Lu Xun's retreat (not voluntarity) was mainly due to the central government's different needs for him.

3. A municipality directly under the Central Government is a city directly under the jurisdiction of the central government. It is not part of any province. In other words, these municipalities can also be called a city, but they are super cities, which are comparable to other provinces that include many cities in terms of population and economic contribution.

4. Autonomous region is a name of administrative division. In the early days of China, ethnic autonomous areas were collectively referred to as autonomous regions. 


\section{Works Cited}

Bo, Jingxi. The Acceptance Process of Lu Xun's Works in Middle School. 2007. Northeast Normal U, PhD dissertation.

Bourdieu, Pierre. The Field of Cultural Production: Essays on Art and Literature. Edited by Randal Johnson, Columbia UP, 1993.

---. In Other Words: Essays towards a Reflexive Sociology. Stanford UP, 1990.

Chang, Lei. Changes of Ancient Poems in Chinese Textbooks. Oriental Outlook. 30 Nov. 2014. www.banyuetan.org/chcontent/zx/mtzd/20141128/118371.shtml.

Chen, Duxiu. "Wo duiyu Luxun zhi renshi" [My Understanding on Lu Xun]. Luxun pingshuo bashi nian [Comments on Lu Xun in the Past Eighty Years]. Edited by Zi Tong, Huaqiao Chubanshe, 2005, pp. 24-25.

Chen, Suyu. Sabo Luxun jingshen de zhongzi [Spread the Weed of LuXun's spirit]. J. of Jiangsu Normal University. (Philosophy and Social Sciences Edition) Vol.39, No.1. Jan., 2013, pp.122-130.

Curriculum Research Institute. Ershi shiji zhongguo zhongxiaoxue kecheng biaozhun: jiaoxue dagang huibian [The Curriculum Standards for Elementary and Middle School in Twentieth Century China: the Compilation of Teaching Syllabus]. People's Education Press, 2001.

Dawson, Raymond, editor. The Legacy of China. Clarendon P, 1964.

Guo, Shaofeng. "The Ministry of Education's clarification on the 'Retreat of Lu Xun.” 13 May 2011, news.sohu.com/20110513/n307416832.shtml.

"Instructions on Educational Work." News of the Communist Party of China, cpc. people.com.cn/GB/64162/64165/70293/70312/. Accessed 20 June 2015.

Kowallis, Jon. The Lyrical Lu Xun: A Study of His Classical-Style Verse. U of Hawaii P, 1996.

Lewin, Keith, et al. Educational innovation in China: Tracing the Impact of the 1985 Reforms. Longman, 1994.

Lovell, Julia. “China’s Conscience.” The Guardian, 12 June 2010, www.theguardian. com/books/2010/jun/12/rereading-julia-lovell-lu-xun.

Lu Xun. Call to Arms. 1922. Translated by Y. Xianyi \& G. Yang. Foreign Languages Press, 2000.

---. "Literature in the Revolutionary Period" [Geming shidai de wenxue]. Complete Works of Lu Xun (Lu Xun quanji), vol. 3, Renmin wenxue chuban she, 1981, pp. 417-424.

Said, Edward. Representations of the Intellectual. Pantheon, 1994.

Sascha. "The Murky Evolution of the Chinese Education System." Chengdu Living. 30 Sept. 2010. www.chengduliving.com/evolution-of-the-chinese-education-system/. 
Shils, Edward. The Intellectuals and the Power and Other Essays. The U of Chicago P, 1972.

Thurston, A. F. Enemies of the People: The Ordeal of the Intellectuals in China's Great Cultural Revolution. Harvard UP, 1988.

Wang Ping, Deng Yue. “The Changes of Lu Xun's Works in Middle School Chinese Textbooks" [ LuXun zuopin zai zhongxue yuwen keben zhongde bianqian]. Language Planning, vol. 11, pp 54-56.

Wen, Lisan. Zhongxue yuwen shiye zhong de Luxun zuopin [Lu Xun's works in Middle School Chinese Textbook]. People's Literature Press, 2003.

Wen, Rumin, et al. Zhongguo xiandangdai wenxue xueke gaiyao [The Outline of Modern and Contemporary Chinese Literature Subject]. Beijing UP, 2005.

Xie, Yong. "Sanshi niandai Taiyuan ge zhongxue guowen shiti" [1930s' Middle School Chinese Test Questions in Taiyuan]. Shenshi zhongxue yuwen jiaoyu [The Suvey on Middle School and High School Chinese Education], edited by Kong Qingdong, Shantou UP, 1999, pp. 365-367.

Zhang, Longhua, editor. Yuwen jiaoyuxue [Chinese Education]. Chongqing Publishing House, 1987.

Zhang, Xinke. "An Essay on a Century's History of Rectification of the Name for Chinese Subject” [Yuwenke bainian zhengmin shilun]. Journal of Fujian Normal University (Philosophy and Social Sciences Edition), no. 6, 2012, pp. 193-203.

Zhou, Haiying and Zhou, Lingfei. "What are Lu Xun's works in Primary, Middle and High School Chinese Textbooks?” Digest of Chinese and Foreign Books 1, 2012, pp. 62-70. 